\title{
Reporting Quality of Clinical Practice Guidelines Regarding Gout and Hyperuricemia According to the RIGHT checklist: Systematic Review
}

\author{
Can Wang \\ The Affiliated Hospital of Qingdao University \\ Xufei Luo \\ School of Public Health of Lanzhou University \\ Maichao Li \\ The Affiliated Hospital of Qingdao University \\ Lingling Cui \\ The Affiliated Hospital of Qingdao University \\ Xinde Li \\ The Affiliated Hospital of Qingdao University \\ Lin Han \\ The Affiliated Hospital of Qingdao University \\ Xuefeng Wang \\ The Affiliated Hospital of Qingdao University \\ Wei Ren \\ The Affiliated Hospital of Qingdao University \\ Yuwei He \\ The Affiliated Hospital of Qingdao University \\ Wenyan Sun \\ The Affiliated Hospital of Qingdao University \\ Changgui Li ( $\sim$ lichanggui@medmail.com.cn) \\ The Affiliated Hospital of Qingdao University \\ Yaolong Chen ( $\nabla$ gssrmyywl2016@163.com ) \\ Institute of Health Data Science of Lanzhou University \\ Zhen Liu ( $\nabla$ cxxz-007@163.com ) \\ The Affiliated Hospital of Qingdao University
}

\author{
Systematic review update \\ Keywords: clinical practice guideline, gout, hyperuricemia, RIGHT check list, reporting quality \\ Posted Date: February 10th, 2021 \\ DOI: https://doi.org/10.21203/rs.3.rs-107411/v2 \\ License: (c) (1) This work is licensed under a Creative Commons Attribution 4.0 International License. Read Full License
}

Version of Record: A version of this preprint was published at Systematic Reviews on April 5th, 2021. See the published version at https://doi.org/10.1186/s13643-021-01645-1. 


\section{Abstract}

Background The Reporting Items for Practice Guidelines in Healthcare (RIGHT) checklist was used to assess the reporting quality of 2009-2019 Clinical Practice Guidelines (CPGs) regarding gout and hyperuricemia, aimed to improve the reporting quality of future guidelines.

Methods We searched PubMed, the Chinese Biomedical Literature database, the Wan Fang Database, and the China National Knowledge Infrastructure from January 2009 to June 2019 for guidelines regarding gout and hyperuricemia. We also searched the websites of guideline development organizations (the Guidelines International Network, the National Institute for Health and Clinical Excellence, the American College of Rheumatology, and the European League Against Rheumatism) (EULAR). Furthermore, supplementary guidelines reported in included articles were systematically searched, as well as Medlive and Google Scholar.

Results Seventeen guidelines were included, of which one was in Chinese and 16 were in English. The mean reporting rate of the 35 items specified was 14.9 (42.5\%), only five CPGs (29.4\%) had a reporting rate $>50 \%$. Of the 35 items, three were very frequently reported. The reporting proportion of the seven domains (Basic information, Background, Evidence, Recommendations, Review and quality assurance, Funding and declaration and management of interests, and Other information) were $64.7 \%, 36.8 \%, 50.6 \% 50.6 \%, 42.9 \%, 8.82 \%, 33.8 \%$, and $31.4 \%$, respectively.

Conclusion The reporting quality of the present guidelines for gout and hyperuricemia is relatively poor. We suggest that the RIGHT reporting checklist should be used by CPG developers to ensure higher reporting quality of future guidelines.

\section{Background}

Gout is a group of heterogeneous diseases caused by long-term disturbance of purine metabolism, which results in a high serum uric acid concentration. The prevalence of gout is $>1 \%$ in most developed countries, and with the recent improvement in living standards, the prevalence of gout is likely to increase[1]. This chronic disease is associated with substantial morbidity and mortality, making it a major global social and economic burden[2]. Furthermore, gout and hyperuricemia can induce and exacerbate metabolic diseases, such as hypertension, diabetes, and disorders of lipid metabolism, besides they are also independent risk factors for stroke and myocardial infarction[3, 4]. Thus, gout and hyperuricemia have become common conditions that seriously affect human health.

With recent advances in pharmaceutical therapies, auxiliary diagnostic methods, and novel treatment approaches, a number of clinical practice guidelines (CPGs) have been developed to standardize the diagnosis and treatment of gout [5-9]. On the basis of evidence provided by systematic reviews, these CPGs have aimed to provide patients with the optimal medical treatment strategy [10]. Decisions regarding diagnosis and therapy are made on the basis of the CPGs, which standardize the behavior of clinicians, with the aims of improving clinical success and reducing cost [11]; therefore, the quality of CPGs is crucially important. There are two quality evaluation methods suitable for CPGs: the Appraisal of Guidelines for Research and Evaluation tool (AGREE) and the Reporting Items for Practice Guidelines in Healthcare (RIGHT) tool [12].

AGREE II (https://www.agreetrust.org/resource-centre/) assesses the methodological rigor and transparency in which a CPG is developed and can be used to guide CPGs development, while RIGHT checklist (http://www.right-statement.org) was developed in order to improve the reporting of practice guidelines. Because of the different purpose, appropriate instrument must be distinguished when address reporting or assess methodological quality [12, 13]. A number of studies have been published that used AGREE II to assess the quality of the gout guidelines, which showed that the current guidelines are of poor quality [8, 14-16]. However, AGREE II does not separate the quality of the report contents from the quality of the methodology of CPGs, Yao et.al recommended RIGHT checklist providing detailed information that lacked in AGREE II [17], meaning that the reporting quality of gout and hyperuricemia guidelines have not been fully assessed [12]. Therefore, in the present study, we evaluated the reporting quality of gout and hyperuricemia CPGs using the RIGHT tool, to compensate previous study using AGREEII, and permit the standardization reporting of future guidelines.

\section{Materials And Methods}

\section{Data source and search strategy}

We searched PubMed, the Chinese Biomedical Literature database (CBM), the Wan Fang Database, and the China National Knowledge Infrastructure (CNKI) from January 2009 to June 2019 for the relevant guidelines. We also searched the websites of the organizations responsible for guideline development: the Guidelines International Network (GIN), the National Institute for Health and Clinical Excellence (NICE), the American College of Rheumatology (ACR), and the European League Against Rheumatism (EULAR). Furthermore, supplementary guidelines reported in the included articles were systematically searched, and we also searched Medlive and Google Scholar for additional material $[8,9,14]$, this project has been registered in OSFHOME (https://osf.io/z4evs/), and search strategy is listed in Supplementary file Table: 1.

\section{Study selection and data extraction}

Inclusion criteria: 'P' gout and/or hyperuricemia; 'I' any intervention; 'C' any comparator or comparison, no 'key' CPG content is of interest; 'A' 2009 to 2019 , English or Chinese; ' $R$ ' no recommendation is of interest [18].

Exclusion criteria: 1) old versions of guidelines, if an updated version was available; 2) interpretations and translations of guidelines; 3 ) repeatedly published guidelines; and 4) guideline for which full text was still not available after contacting authors. 
Data extraction: Two researchers (Zhen Liu and Can Wang) searched the database, all retrieved studies were screened using EndNote X8. After eliminating duplicates, the titles and abstracts were first screened according to the inclusion criteria, and the reasons for exclusion were recorded. Next, full text of the literature that met the inclusion criteria were screened again, and determined whether the retrieved guidelines met the study criteria. Then, independent screening and cross-checking of the guidelines were carried out. Differences between reviewers were resolved through discussion or consultation with a third party (Yaolong Chen and his team).

\section{Reporting quality assessment}

The RIGHT tool (supplementary material or http://www.right-statement.org) was used to evaluate the eligibility guidelines included in this study. The tool consists of 22 key items and 35 sub-items (Supplementary file Table: 2), which are divided into the following seven areas: Basic information (items 1-4), Background (items 5-9), Evidence (items 10-12), Recommendations (items 13-15), Review and quality assurance (items 16-17), Funding and declaration and management of interests (items 18-19), and Other information (items 20-22). Each item was independently scored by two researchers, and most of the items were graded dichotomously, as "reported" $(\mathrm{Y})$ or "unreported" $(\mathrm{N})$. "Reported" meant that the relevant information was fully reported, whereas "unreported" meant the relevant information was unavailable. However, "partially reported" (P) was also used to indicate that the guideline contained only partial information, and when the guideline evaluation did not apply to the item, "not applicable" (NA) was recorded. We reported the results for each item as absolute quantities and percentages. For each item, we also reported the number and percentage of projects reported by each guideline. If the reporting proportion of the guidelines was $<50 \%$, the quality of the item was regarded as low [13]. The data were extracted and analyzed using Excel 2016 (Microsoft Corp., Redmond, WA, USA).

\section{Results}

\section{Results of the selection}

A total of 765 records were identified through database searching. Four other records were identified via the guideline development organization websites and Google Scholar. Of these, 17 guidelines that met the criteria were analyzed (Fig: 1).

\section{Characteristics of the included CPGs}

Of the 17 CPGs, one was in Chinese and 16 were in English. Nine were developed by European countries (52.9\%), of which four were developed by EULAR (23.5\%); six originated from the United States (35.3\%), of which three were developed by ACR (17.6\%) and three (17.6\%) by universities (University of Texas, Tokyo Women's Medical University, University of Texas). The remaining two (11.8\%) were developed by the Evidence, Expertise, and Exchange initiative. The features of each are summarized (Table: 1$)$.

\section{Overall reporting quality}

The mean reporting rate of the 35 items was 14.9 (42.5\%) and it ranged from nine (25.7\%) to 22 (62.9\%) for the 17 CPGs (Fig: 2 ). Of the 17 CPGs, only five $(29.4 \%)$ had a reporting rate $>50 \%$. The best one reported $62.9 \%$ of the items, while the poorest two reported $<26 \%$ of the 35 items.

Of the 35 items, the most frequently reported were \#11a (Indicate whether the guideline is based on new systematic reviews done specifically for this guideline or whether existing systematic reviews were used), \#12 (Describe the approach used to assess the certainty of the body of evidence), and \#13c (Indicate the strength of the recommendations and the certainty of the supporting evidence), which were reported in 16 ( $94.1 \%$ ) guidelines. These were followed by \#13a (Provide clear, precise, and actionable recommendations), which was reported in 15 (88.2\%) CPGs. Items \#8b (Describe the setting(s) for which the guideline is intended, such as primary care, low- and middle-income countries, or inpatient facilities) and \#17 (Indicate whether the guideline was subjected to a quality assurance process. If yes, describe the process) were reported in none of the CPGs (Fig: 3) (Table: 2).

According to the RIGHT tool, the reporting rates of the seven domains (Basic information, Background, Evidence, Recommendations, Review and quality assurance, Statements and management of funds and interests, and Other information) were $64.7 \%, 36.8 \%, 50.6 \% 50.6 \%, 42.9 \%, 8.82 \%, 33.8 \%$, and $31.4 \%$, respectively.

\section{Subgroup analysis}

According to the geographical regions of the sponsors or participants, nine CPGs were participated in or initiated by European countries, and 6 CPGs were originated from American countries. Firstly, the mean number of reporting items of the $9 \mathrm{CPGs}$ developed by European countries was 15.2 , and only 3 CPGs had a compliance rate of $>50 \%$ (33.3\%); four of these 9 CPGs were EULAR-generated冈the mean number of reporting items in these 4 CPGs was 15.8 . Secondly, as for the six guidelines developed in the United States, the mean number of reporting item was 14.8 . Two of these 6 CPGs were prepared by the ACR, with a mean number of reporting items of 16.5, and two were published on NGC (National Guideline Clearinghouse), reported only nine items. Twentytwo items were reported in the American College of Physicians (ACP) guideline, which was the guideline with the largest number of reporting items among the 17 included in the analysis.

Eight guidelines were published between 2009 and 2014, which had a mean of 13.9 reporting items, and only one (12.5\%) guideline had a compliance rate of more than $50 \%$. Between 2015 and 2019, a total of nine guidelines were published, with a mean of 15.8 items being reported, but only four (44.4\%) had a compliance rate of $>50 \%$. 
Basic information

With regard to the basic information, most of the CPGs could be judged by their title ( $82.4 \%$ ), and the contact information for at least one author could be found (82.4\%). The classification of the guidelines could be easily discerned in $76.5 \%$ of the CPGs and a summary was presented in $70.5 \%$. However, only $29.4 \%$ of the CPGs reported a publication date. Forty-one-point-two percent of the CPGs defined new terms and gave corresponding acronyms.

Background

The 17 CPGs did not comprehensively describe the background. More than half reported the epidemiology of gout (52.9\%). Six (35.3\%) guidelines reported the overall objectives of the guidelines and the specific objectives they were designed to achieve. Most of the guidelines described the main target population (76.5\%), but only $17.6 \%$ described the subgroups that should be considered. Fewer than half (47.1\%) of the guidelines described the key users and other potential users of the guidelines, and none described the specific target environment. Six (35.3\%) CPGs listed all the contributors and their roles, and six (35.3\%) gave the titles and affiliations of all the participants in their development, but only four (23.5\%) contained both sets of information.

Evidence

Seven (41.2\%) of the guidelines described the key findings on which the recommendations were based, but only two described the selection and classification of outcomes, and only one reported both. Sixteen (94.1\%) guidelines described whether the systematic reviews on which the guidelines were based had been recently completed, but only two (11.8\%) presented references, described how they were retrieved and evaluated, and stated whether they had been updated. Only one CPG did not describe the method of evaluation and grading of the quality of evidence.

Recommendations

Most of the guidelines $(15,80.2 \%)$ provided clear, accurate, and enforceable recommendations. Sixteen (94.1\%) CPGs described the strength of the recommendation and the quality of the evidence supporting it, but only four provided recommendations for subgroups. Four CPGs took into account the preferences and values of the target group, two (11.8\%) took into account cost and resource utilization, two (11.8\%) took into account fairness, feasibility and acceptability, when creating their recommendations. Most of the guidelines (15,88.2\%) described the decision-making process and the methods used by the working group that created the guideline.

Review and quality assurance

Only three (17.6\%) CPGs described whether they had been sent for review or not, and none described the level of supervision involved.

Funding and declaration and management of interests

More than half of the CPGs $(9,52.9 \%)$ described the sources of funding at each stage of their development, but only one described the role of the sponsor in the different stages of guideline formulation, as well as in the dissemination and implementation of the recommendations. Similarly, most of the CPGs (11, $64.7 \%$ ) described the types of conflict of interest associated, but only two (11.8\%) described the evaluation and management of these conflicts of interest and how users of the guidelines could obtain this information.

Other information

Eleven (64.7\%) CPGs described where the guidelines, corresponding attachments, and other related documents could be obtained. However, only three (17.6\%) articles described the differences between current practice and that recommended by research evidence, and/or provided recommendations for future research. In addition, only two CPGs described all the limitations associated with the formulation of the guidelines and their possible impact on the effectiveness of the recommendations.

\section{Discussion}

The quality of CPGs about gout and hyperuricemia were assessed before with AGREE II[5], whereas AGREE II and RIGHT checklist had unique items by themselves [17]; the RIGHT checklist added new and detailed items that AGREE II lacked. We assessed the reporting quality of CPGs in the field of gout and hyperuricemia, using the RIGHT checklist in our study, to help guideline developers better standardizing the reporting quality of future CPGs. Furthermore, it also could help healthcare professionals better understand and implement the contents of such CPGs [12]. We used the RIGHT checklist to evaluate 17 guidelines for gout and hyperuricemia of various types that had been prepared in different geographical regions over the past 10 years, and found that they varied in quality. Of the $17 \mathrm{CPGs}$, only five reported $>50 \%$ of the items in the RIGHT tool, suggesting that many were of low reporting quality. This finding is similar to that made previously using the AGREE囚tool [14].

Among the seven sections of the RIGHT tool, the reporting rate of Basic information was the highest ( $64.7 \%)$, followed by Evidence (50.6\%), but the reporting rate of the other sections was $<50 \%$. The most poorly reported section was the Declaration and management of funds and interests, with only $8.8 \%$ of CPGs reporting these items. This suggests that the guideline creators are generally good at including basic information, but that review and quality assurance are easily ignored.

Most of the CPGs were written by European and American organizations, and the overall completeness of the guidelines was slightly better in Europe than that in the United States. However, the scores for the CPGs written by the ACR and ACP, which are influential guideline-writing organizations in the United

Page 4/12 
States, were higher than those for EULAR-generated CPGs. This shows that there are differences in reporting quality of the CPGs written by different organizations in different geographical regions. With regard to the relationship between publication date and score, the compilation of guidelines has greatly improved in recent years. The guideline writers have aimed to correct the deficits of the previous CPGs with regard to the practical applications of the guidelines, but the emergence of guideline-based systematic reviews in recent years have also made them consider writing their guidelines in accordance with certain norms.

\section{Analysis of the reporting quality of guidelines regarding gout and hyperuricemia}

Basic information: Most of the CPGs had a high reporting rate for basic information, but there were still some in which the year of publication was not clear and there was ambiguity in the definitions of acronyms. These issues are very important for researchers and practitioners who wish to know how up-to-date guidelines are, and it is necessary to interpret vague terms and acronyms for more accurate understanding of the guidelines.

Background: In the background to the CPGs, the writers usually described the main target groups for the guidelines and discussed the epidemiology of the problems described. However, the other items were frequently not well reported. For example, the inclusion of 8 a (the main users of the guide should be described) and $8 b$ (the specific environment for which the guide should be described) demonstrate that the application of the guidelines will vary for different users and different environments. For example, for low- and middle-income people, it is necessary to consider the economic benefits [13]. Therefore, the background to the guidelines should be described in detail.

Evidence: About half of the items in the Evidence section were reported, and items 10b (the methodology for the selection and classification of outcomes should be described) and 11b (if guide makers use published systematic reviews, references should be given and describe how they were retrieved and evaluated) had low reporting rates. Items $10 \mathrm{~b}$ and $11 \mathrm{~b}$ can greatly help researchers and practitioners to understand the evidence and assess the accuracy of the guidelines. Furthermore, they are important for peer review, because they permit shortcomings in the CPGs to be found and remedied. Items $10 \mathrm{~b}$ and $11 \mathrm{~b}$ can also be supplemented as new evidence accumulates over time.

Recommendations: Most of the guidelines did not make recommendations for subgroups, suggesting that the writers did not regard subgroups as important. Most writers did not consider items 14a (whether to consider the preferences and values of the target population), 14b (whether to consider cost and resource utilization), or 14c (whether to consider fairness, feasibility, and acceptability), or they considered these issues but did not included them in the CPGs. This means that healthcare professionals cannot easily adapt the CPGs according to different clinical situations.

Review and quality assurance: Items in this section were described in only a small number of guidelines, such that the reporting rate was the lowest for all the sections. Some of the guidelines may have been independently reviewed and quality-controlled, but the absence of such information is likely to make guide users and peer reviewers doubt the quality of the guidelines.

Funding and declaration and management of interests: The RIGHT checklist showed that the quality of the published CPGs was low with regard to this aspect, suggesting that the writers did not pay enough attention to it. A lack of information of this section may lead to the inference that the recommendations of these CPGs could have been influenced by multiple interested parties, which would lower the credibility of the guidelines, especially with regard to specific treatment recommendations.

Other information: Most of the CPGs failed to differentiate evidence obtained from practice and research, or to provide recommendations for future research (or both). They also failed to describe the limitations in the formulation of the CPGs and the possible impact of these limitations on the effectiveness of the recommendations. Such content could have provided a reference for guide users to appropriately use the recommendations, and provided guidance for future updates and other researchers.

\section{Strengths and limitation}

Strengths: This is the first study to use the RIGHT tool to evaluate the reporting quality of CPGs in the field of gout and hyperuricemia. In addition, the methods of systematic retrieval, screening, and evaluation were adopted, and the quality of the outcome measurements was strictly controlled.

Limitations: First, only guidelines written in Chinese and English were included, this might cause language bias. Second, only CPGs published in journals and online regarding gout and hyperuricemia were included; CPGs published in the form of books or government documents were not analyzed.

\section{Conclusion}

In conclusion, by using the RIGHT checklist to evaluate CPGs in the field of gout and hyperuricemia, we found that their standards substantially differed, unfortunately most of the current CPGs had relatively low scores. The RIGHT evaluation form is a comprehensive tool for the evaluation of the reporting quality of such guidelines. CPGs with poor reporting quality cannot perform its' due role, on the contrary, it may mislead users and lead to wrong diagnosis and treatment, resulting in a waste of medical resources and delay of the disease. We suggest organizations that participate in reporting of CPGs regarding gout and hyperuricemia to use RIGHT tool, so as to improve standardization of reporting, making the reporting clear, complete and transparent.

\section{Abbreviations}

RIGHT: Reporting Items for Practice Guidelines in Healthcare

CPGs: Clinical Practice Guidelines 
EULAR: European League Against Rheumatism

AGREE: Appraisal of Guidelines for Research and Evaluation tool

CBM: Chinese Biomedical Literature database

CNKI: China National Knowledge Infrastructure

GIN: Guidelines International Network

NICE: National Institute for Health and Clinical Excellence

ACR: American College of Rheumatology

NGC: National Guideline Clearinghouse

ACP: American College of Physicians

\section{Declarations}

Funding: This study was supported by the National Natural Science Foundation of China (grant numbers 81520108007, 81770869, and 81801434), the Natural Science Foundation of Shandong Province (grant number ZR2018ZC1053), the Qingdao Applied Basic Research Project (grant number 19-6-2-53cg), and the Shandong Province Key Research and Development Program (grant number 2018CXGC1207).

Conflicts of interest: The authors declare that they have no conflict of interest.

Ethics approval: This article does not contain any studies conducted on human participants or animals that required ethics approval.

Consent for publication $\square$ All authors have approved the manuscript and agree with this submission .

Authors' contributions: Can Wang, Xufei Luo, and Maichao Li contributed equally to this work. Xufei Luo and Yaolong Chen designed the study. Can Wang, Zhen Liu, and Maichao Li conducted the evaluation, wrote the manuscript, and complement the methods of this study. Xufei Luo and Yaolong Chen supplied methodological assistance. Changgui Li supplied funding and helped revise the manuscript. All authors provided input regarding the direction of the study and the content of the paper. All authors approved the final version of the paper.

\section{Acknowledgments}

We thank colleagues from the Evidence-Based Medicine Center, School of Basic Medical Sciences, and Lanzhou University (Lanzhou, China), including Xufei Luo and Yaolong Chen, for their kind suggestions and assistance with the study.

\section{References}

1 Kuo CF, Grainge MJ, Zhang W, Doherty M. Global epidemiology of gout: prevalence, incidence and risk factors. Nat Rev Rheumatol 2015;11(11):649-62.

2 Rai SK, Burns LC, De Vera MA, Haji A, Giustini D, Choi HK. The economic burden of gout: A systematic review. Semin Arthritis Rheum 2015;45(1):75-80.

3 Shiozawa A, Szabo SM, Bolzani A, Cheung A, Choi HK. Serum Uric Acid and the Risk of Incident and Recurrent Gout: A Systematic Review. J Rheumatol 2017;44(3):388-96.

4 MacFarlane LA, Kim SC. Gout: a review of nonmodifiable and modifiable risk factors. Rheum Dis Clin North Am 2014;40(4):581-604.

5 Wang D, Yu Y, Chen Y, et al. Assessing the Quality of Global Clinical Practice Guidelines on Gout Using AGREE II Instrument. J Clin Rheumatol 2020;26(2):54-9.

6 Yu Y, Wang D, Zhou Q, et al. Recommendations in clinical practice guidelines on gout: systematic review and consistency analysis. Clin Exp Rheumatol 2020.

7 Ughi N, Prevete I, Ramonda R, et al. The Italian Society of Rheumatology clinical practice guidelines for the diagnosis and management of gout. Reumatismo 2019;71(S1):50-79.

8 Li Q, Li X, Wang J, et al. Diagnosis and treatment for hyperuricemia and gout: a systematic review of clinical practice guidelines and consensus statements. BMJ Open 2019;9(8):e026677.

9 Yang N, Yu Y, Zhang A, et al. Reporting, presentation and wording of recommendations in clinical practice guideline for gout: a systematic analysis. BMJ Open 2019;9(1):e024315.

10 Guidelines loMCoSfDTCP, Graham R, Mancher M. Clinical practice guidelines we can trust. National Academies Press Washington, DC; 2011. 
11 Grilli R, Magrini N, Penna A, Mura G, Liberati A. Practice guidelines developed by specialty societies: the need for a critical appraisal. Lancet 2000;355(9198):103-6.

12 Chen Y, Yang K, Marusic A, et al. A Reporting Tool for Practice Guidelines in Health Care: The RIGHT Statement. Ann Intern Med 2017;166(2):128-32.

13 Xiao Y, Jiang L, Tong Y, et al. Evaluation of the quality of guidelines for assisted reproductive technology using the RIGHT checklist: A cross-sectional study. Eur J Obstet Gynecol Reprod Biol 2019;241:42-8.

14 Wang D, Yu Y, Chen Y, et al. Assessing the Quality of Global Clinical Practice Guidelines on Gout Using AGREE II Instrument. J Clin Rheumatol 2018.

15 Collaboration A. Development and validation of an international appraisal instrument for assessing the quality of clinical practice guidelines: the AGREE project. Qual Saf Health Care 2003;12(1):18-23.

16 Oxman AD, Schunemann HJ, Fretheim A. Improving the use of research evidence in guideline development: 16. Evaluation. Health Res Policy Syst 2006;4:28.

17 Yao X, Ma J, Wang Q, Kanters D, Ali MU, Florez ID. A Comparison of AGREE and RIGHT: which Clinical Practice Guideline Reporting Checklist Should Be Followed by Guideline Developers? J Gen Intern Med 2020;35(3):894-8.

18 Johnston A, Kelly SE, Hsieh SC, Skidmore B, Wells GA. Systematic reviews of clinical practice guidelines: a methodological guide. J Clin Epidemiol 2019;108:64-76.

19 Richette P, Doherty M, Pascual E, et al. 2018 updated European League Against Rheumatism evidence-based recommendations for the diagnosis of gout. Annals of the rheumatic diseases 2019:annrheumdis-2019-215315.

$20 \mathrm{Yu} \mathrm{KH}$, Chen DY, Chen JH, et al. Management of gout and hyperuricemia: multidisciplinary consensus in Taiwan. International journal of rheumatic diseases 2018;21(4):772-87.

21 Hui M, Carr A, Cameron S, et al. The British Society for Rheumatology Guideline for the Management of Gout. Rheumatology (Oxford) 2017;56(7):e1e20.

22 Qaseem A, McLean RM, Starkey M, Forciea MA, Clinical Guidelines Committee of the American College of P. Diagnosis of Acute Gout: A Clinical Practice Guideline From the American College of Physicians. Ann Intern Med 2017;166(1):52-7.

23 Qaseem A, Harris RP, Forciea MA, Clinical Guidelines Committee of the American College of P. Management of Acute and Recurrent Gout: A Clinical Practice Guideline From the American College of Physicians. Ann Intern Med 2017;166(1):58-68.

24 Chinese Rheumatology A. [2016 China gout clinical practice guideline]. Zhonghua Nei Ke Za Zhi 2016;55(11):892-9.

25 Richette P, Doherty M, Pascual E, et al. 2016 updated EULAR evidence-based recommendations for the management of gout. Ann Rheum Dis 2017;76(1):29-42.

26 Kiltz U, Smolen J, Bardin T, et al. Treat-to-target (T2T) recommendations for gout. Ann Rheum Dis 2017;76(4):632-8.

27 Graf SW, Whittle SL, Wechalekar MD, et al. Australian and New Zealand recommendations for the diagnosis and management of gout: integrating systematic literature review and expert opinion in the 3e Initiative. International journal of rheumatic diseases 2015;18(3):341-51.

28 Neogi T, Jansen TL, Dalbeth N, et al. 2015 Gout classification criteria: an American College of Rheumatology/European League Against Rheumatism collaborative initiative. Ann Rheum Dis 2015;74(10):1789-98.

29 Araújo F, Cordeiro I, Teixeira F, et al. Portuguese recommendations for the diagnosis and management of gout. Acta reumatologica portuguesa 2014;39(2):158-71.

30 Spanish Society of Rheumatology (SER). Clinical Practice Guidelines for Management of Gout. In. www.formacionsanitaria.com; 2013.

31 Sivera F, Andres M, Carmona L, et al. Multinational evidence-based recommendations for the diagnosis and management of gout: integrating systematic literature review and expert opinion of a broad panel of rheumatologists in the 3e initiative. Ann Rheum Dis 2014;73(2):328-35.

32 Manara M, Bortoluzzi A, Favero M, et al. Italian Society of Rheumatology recommendations for the management of gout. Reumatismo $2013: 4-21$.

33 The University of Texas at Austin SoN, Family Nurse Practitioner Program, . Management of chronic gout in adults. In.

https://www.ahrq.gov/gam/index.html; 2012.

34 Khanna D, Fitzgerald JD, Khanna PP, et al. 2012 American College of Rheumatology guidelines for management of gout. Part 1: systematic nonpharmacologic and pharmacologic therapeutic approaches to hyperuricemia. Arthritis Care Res (Hoboken) 2012;64(10):1431-46. 
35 Khanna D, Khanna PP, Fitzgerald JD, et al. 2012 American College of Rheumatology guidelines for management of gout. Part 2: therapy and antiinflammatory prophylaxis of acute gouty arthritis. Arthritis Care Res (Hoboken) 2012;64(10):1447-61.

36 Yamanaka H, Japanese Society of G, Nucleic Acid M. Japanese guideline for the management of hyperuricemia and gout: second edition. Nucleosides Nucleotides Nucleic Acids 2011;30(12):1018-29.

37 The University of Texas at Austin SoN, Family Nurse Practitioner Program, . Management of initial gout in adults. In. https://www.ahrq.gov/gam/index.html; 2009.

\section{Tables}

Table: 1 Characteristics of included CPGs

\begin{tabular}{|c|c|c|c|c|c|}
\hline $\begin{array}{c}\text { Serial } \\
\text { number }\end{array}$ & Title & $\begin{array}{c}\text { Published } \\
\text { date }\end{array}$ & Developer & Nation & Published journal \\
\hline 1 & $\begin{array}{l}2018 \text { updated European League Against Rheumatism evidence-based recommendations for the } \\
\text { diagnosis of gout[19] }\end{array}$ & 2019 & $\begin{array}{l}\text { European League Against } \\
\text { Rheumatism. }\end{array}$ & Europe & $\begin{array}{l}\text { Annals of the } \\
\text { Rheumatic } \\
\text { Diseases }\end{array}$ \\
\hline 2 & Management of gout and hyperuricemia: Multidisciplinary consensus in Taiwan[20] & 2018 & Astellas, Taiwan & $\begin{array}{l}\text { Taiwan } \\
\text { China }\end{array}$ & $\begin{array}{l}\text { SPECIAL } \\
\text { EDITORIAL } \\
\text { REVIEW }\end{array}$ \\
\hline 3 & The British Society for Rheumatology Guideline for the Management of Gout[21] & 2017 & $\begin{array}{l}\text { British Society for Rheumatology } \\
\text { Standards, Audit and Guidelines } \\
\text { Working Group. }\end{array}$ & UK & RHEUMATOLOGY \\
\hline 4 & $\begin{array}{l}\text { 1.Diagnosis of Acute Gout: A Clinical Practice Guideline From the American College of } \\
\text { Physicians[22] } \\
\text { 2.Management of Acute and Recurrent Gout: A Clinical Practice Guideline From the American } \\
\text { College of Physicians[23] }\end{array}$ & 2017 & American College of Physicians & USA & $\begin{array}{l}\text { Annals of Internal } \\
\text { Medicine }\end{array}$ \\
\hline 5 & [2016 China Gout Clinical Practice Guideline][24] & 2016 & Rheumatology & China & $\begin{array}{l}\text { Zhonghua Nei Ke } \\
\text { Za Zhi }\end{array}$ \\
\hline 6 & 2016 updated EULAR evidence-based recommendations for the management of gout[25] & 2016 & $\begin{array}{lll}\text { European } & \text { League } & \text { Against } \\
\text { Rheumatism } & & \\
\end{array}$ & Europe & $\begin{array}{l}\text { Clinical and } \\
\text { epidemiological } \\
\text { research }\end{array}$ \\
\hline 7 & Treat-to-target (T2T) recommendations for gout[26] & 2016 & $\begin{array}{lll}\text { European } & \text { League } & \text { Against } \\
\text { Rheumatism } & & \\
\end{array}$ & Europe & $\begin{array}{l}\text { Annals of the } \\
\text { Rheumatic } \\
\text { Diseases }\end{array}$ \\
\hline 8 & $\begin{array}{l}\text { Australian and New Zealand recommendations for the diagnosis and management of gout: } \\
\text { integrating systematic literature review and expert opinion in the 3e Initiative[27] }\end{array}$ & 2015 & $\begin{array}{l}\text { APLAR, Asia Pacific League of } \\
\text { Associations for Rheumatology }\end{array}$ & $\begin{array}{l}\text { Australian } \\
\text { and New } \\
\text { Zealand }\end{array}$ & $\begin{array}{l}\text { International } \\
\text { Journal of } \\
\text { Rheumatic } \\
\text { Diseases }\end{array}$ \\
\hline 9 & $\begin{array}{l}2015 \text { Gout classification criteria: an American College of Rheumatology/European League } \\
\text { Against Rheumatism collaborative initiative[28] }\end{array}$ & 2015 & ACR/EULAR & $\begin{array}{ll}\text { USA } & \text { and } \\
\text { Europe }\end{array}$ & $\begin{array}{l}\text { Annals of the } \\
\text { Rheumatic } \\
\text { Diseases }\end{array}$ \\
\hline 10 & Portuguese recommendations for the diagnosis and management of Gout[29] & 2014 & $\begin{array}{l}\text { A panel of } 78 \text { international } \\
\text { rheumatologists in 3e (Evidence, } \\
\text { Expertise, Exchange) Initiative }\end{array}$ & Portugal & PRÁTICA CLÍNICA \\
\hline 11 & Clinical Practice Guidelines for Management of Gout[30] & 2013 & \begin{tabular}{|ll} 
Spanish Society of \\
Rheumatology
\end{tabular} & Spain & guipclingot \\
\hline 12 & $\begin{array}{l}\text { Multinational evidence-based recommendations for the diagnosis and management of gout: } \\
\text { integrating systematic literature review and expert opinion of a broad panel of rheumatologists } \\
\text { in the } 3 \text { e initiative[31] }\end{array}$ & 2013 & $\begin{array}{l}\text { 3e (Evidence, Expertise, } \\
\text { Exchange) } \\
\text { Initiative/A panel of } \\
\text { international rheumatologists }\end{array}$ & International & $\begin{array}{l}\text { Annals of the } \\
\text { Rheumatic } \\
\text { Diseases }\end{array}$ \\
\hline 13 & Italian Society of Rheumatology recommendations for the management of gout[32] & 2013 & Italian Society of Rheumatology & Italy & Reumatismo \\
\hline 14 & Management of chronic gout in adults[33] & 2012 & University of Texas & USA & $\begin{array}{l}\text { National } \\
\text { Guideline } \\
\text { Clearinghouse }\end{array}$ \\
\hline 15 & $\begin{array}{l}\text { 1.2012 American College of Rheumatology Guidelines for Management of Gout. Part 1: } \\
\text { Systematic Nonpharmacologic and Pharmacologic Therapeutic Approaches to } \\
\text { Hyperuricemia[34] } \\
\text { 2.2012 American College of Rheumatology } \\
\text { Guidelines for Management of Gout. Part 2: Therapy and Anti-inflammatory Prophylaxis of } \\
\text { Acute Gouty Arthritis[35] }\end{array}$ & 2012 & $\begin{array}{lll}\text { American } & \text { College } & \text { of } \\
\text { Rheumatology } & & \\
\end{array}$ & USA & $\begin{array}{l}\text { Arthritis Care \& } \\
\text { Research }\end{array}$ \\
\hline 16 & Japanese Guideline for the Management of Hyperuricemia and Gout: Second Edition[36] & 2011 & $\begin{array}{l}\text { Tokyo Women's Medical } \\
\text { University }\end{array}$ & Japan & $\begin{array}{l}\text { Nucleosides, } \\
\text { Nucleotides and } \\
\text { Nucleic Acids }\end{array}$ \\
\hline 17 & Management of initial gout in adults [37] & 2009 & University of Texas & USA & $\begin{array}{l}\text { National } \\
\text { Guideline } \\
\text { Clearinghouse }\end{array}$ \\
\hline
\end{tabular}

Table: 2 Quality of the guidelines, according to the reporting of each item on the RIGHT checklist 


\begin{tabular}{|c|c|c|c|c|c|c|c|c|c|c|c|c|c|c|c|c|c|c|c|}
\hline & & 17 & 16 & 15 & 14 & 13 & 12 & 11 & 10 & 9 & 8 & 7 & 6 & 5 & 4 & 3 & 2 & 1 & \\
\hline & & $\begin{array}{l}2009 \\
\text { FNPP }\end{array}$ & $\begin{array}{l}2011 \\
\text { TWMU }\end{array}$ & $\begin{array}{l}2012 \\
\text { ACR }\end{array}$ & $\begin{array}{l}2012 \\
\text { FNPP }\end{array}$ & $\begin{array}{l}2013 \\
\text { SIR }\end{array}$ & \begin{tabular}{|l|}
2013 \\
$3 E$
\end{tabular} & $\begin{array}{l}2013 \\
\text { SER }\end{array}$ & $\begin{array}{l}2014 \\
\text { PORTUGAL }\end{array}$ & 2015ACR/EULAR & \begin{tabular}{|l|}
2015 \\
APLAR
\end{tabular} & $\begin{array}{l}2016 \\
\text { T2T }\end{array}$ & \begin{tabular}{|l}
2016 \\
EULAR
\end{tabular} & \begin{tabular}{|l|}
2016 \\
CMA
\end{tabular} & $\begin{array}{l}2017 \\
\text { ACP }\end{array}$ & $\begin{array}{l}2017 \\
\text { BSR }\end{array}$ & \begin{tabular}{|l|}
2018 \\
TRA
\end{tabular} & $\begin{array}{l}2019 \\
\text { ELAR }\end{array}$ & total \\
\hline \multirow[t]{5}{*}{ basic information } & $1 \mathrm{a}$ & $\mathrm{N}$ & $\mathrm{Y}$ & $\bar{Y}$ & $\mathrm{~N}$ & $\mathrm{Y}$ & $\mathrm{Y}$ & $\mathrm{Y}$ & $\mathrm{Y}$ & $\mathrm{N}$ & $\mathrm{Y}$ & $\bar{Y}$ & $\mathrm{Y}$ & $\mathrm{Y}$ & $\bar{Y}$ & $\mathrm{Y}$ & $\mathrm{Y}$ & $\mathrm{Y}$ & 14 \\
\hline & $1 \mathrm{~b}$ & $\mathrm{~N}$ & $\mathrm{~N}$ & $\mathrm{Y}$ & $\mathrm{N}$ & $\mathrm{N}$ & $\mathrm{N}$ & $\mathrm{N}$ & $\mathrm{N}$ & $\mathrm{Y}$ & $\mathrm{N}$ & $\mathrm{N}$ & $\mathrm{Y}$ & $\mathrm{Y}$ & $\mathrm{N}$ & $\mathrm{N}$ & $\mathrm{N}$ & $\mathrm{Y}$ & 5 \\
\hline & 1c & $\mathrm{Y}$ & $\mathrm{Y}$ & $\mathrm{Y}$ & $\mathrm{Y}$ & $\mathrm{Y}$ & $\mathrm{Y}$ & $\mathrm{Y}$ & $\mathrm{Y}$ & $\mathrm{Y}$ & $\mathrm{Y}$ & $\mathrm{N}$ & $\mathrm{Y}$ & $\mathrm{N}$ & $\mathrm{Y}$ & $\mathrm{N}$ & $\mathrm{N}$ & $\mathrm{Y}$ & 13 \\
\hline & 2 & $\mathrm{P}$ & $\mathrm{Y}$ & $\bar{Y}$ & $\mathrm{P}$ & $\mathrm{Y}$ & $\mathrm{Y}$ & $\mathrm{N}$ & $\bar{Y}$ & $\mathrm{Y}$ & $\mathrm{Y}$ & $\mathrm{Y}$ & $\mathrm{Y}$ & $\mathrm{N}$ & $\mathrm{Y}$ & $\mathrm{N}$ & $\mathrm{Y}$ & $\mathrm{Y}$ & 12 \\
\hline & 3 & $\mathrm{~N}$ & $\mathrm{~N}$ & $\mathrm{P}$ & $\mathrm{N}$ & $\mathrm{P}$ & $\mathrm{Y}$ & $\mathrm{Y}$ & $\mathrm{Y}$ & $\mathrm{N}$ & $\mathrm{N}$ & $\mathrm{Y}$ & $\mathrm{P}$ & $\mathrm{N}$ & $\mathrm{Y}$ & $\mathrm{N}$ & $\mathrm{Y}$ & $\mathrm{Y}$ & 7 \\
\hline total & & 1 & 4 & 5 & 1 & 4 & 5 & 3 & 5 & 4 & 4 & 4 & 5 & 4 & 5 & 2 & 4 & 6 & 66 \\
\hline \multirow[t]{7}{*}{ background } & 5 & $\mathrm{~N}$ & $\mathrm{~N}$ & $\mathrm{Y}$ & $\mathrm{N}$ & $\mathrm{Y}$ & $\mathrm{P}$ & $\mathrm{Y}$ & $\mathrm{N}$ & $\mathrm{Y}$ & $\mathrm{Y}$ & $\mathrm{N}$ & $\mathrm{P}$ & $\mathrm{Y}$ & $\mathrm{Y}$ & $\mathrm{Y}$ & $\mathrm{Y}$ & $\mathrm{P}$ & 9 \\
\hline & 6 & $\mathrm{~N}$ & $\mathrm{Y}$ & $\mathrm{Y}$ & $\mathrm{Y}$ & $\mathrm{N}$ & $\mathrm{N}$ & $\mathrm{Y}$ & $\mathrm{P}$ & $\mathrm{N}$ & $\mathrm{P}$ & $\mathrm{P}$ & $\mathrm{N}$ & $\mathrm{N}$ & $\mathrm{Y}$ & $\mathrm{Y}$ & $\mathrm{N}$ & $\mathrm{P}$ & 6 \\
\hline & $7 a$ & $\mathrm{Y}$ & $\mathrm{Y}$ & $\mathrm{Y}$ & $\mathrm{Y}$ & $\mathrm{N}$ & $\mathrm{N}$ & $\mathrm{N}$ & $\mathrm{N}$ & $\mathrm{Y}$ & $\mathrm{Y}$ & $\mathrm{Y}$ & $\mathrm{Y}$ & \begin{tabular}{|l}
$Y$ \\
\end{tabular} & $\mathrm{Y}$ & $\mathrm{Y}$ & $\mathrm{Y}$ & $\mathrm{Y}$ & 13 \\
\hline & $7 \mathrm{~b}$ & $\mathrm{~N}$ & $\mathrm{Y}$ & $\mathrm{N}$ & $\mathrm{N}$ & $\mathrm{N}$ & $\mathrm{N}$ & $\mathrm{N}$ & $\mathrm{N}$ & $\mathrm{N}$ & $\mathrm{N}$ & $\mathrm{N}$ & $\mathrm{Y}$ & $\mathrm{N}$ & $\mathrm{N}$ & $\mathrm{Y}$ & $\mathrm{N}$ & $\mathrm{N}$ & 3 \\
\hline & $8 a$ & $\mathrm{Y}$ & $\mathrm{N}$ & $\mathrm{Y}$ & $\mathrm{Y}$ & $\mathrm{N}$ & $\mathrm{N}$ & $\mathrm{Y}$ & $\mathrm{N}$ & $\mathrm{N}$ & $\mathrm{N}$ & $\mathrm{N}$ & $\mathrm{P}$ & $Y$ & $\mathrm{Y}$ & $\mathrm{Y}$ & $\mathrm{Y}$ & $\mathrm{P}$ & 8 \\
\hline & $8 \mathrm{~b}$ & $\mathrm{~N}$ & $\mathrm{~N}$ & $\mathrm{~N}$ & $\mathrm{~N}$ & $\mathrm{~N}$ & $\mathrm{~N}$ & $\mathrm{~N}$ & $\mathrm{~N}$ & $\mathrm{~N}$ & \begin{tabular}{|l}
$\mathrm{N}$ \\
\end{tabular} & $\mathrm{N}$ & $\mathrm{N}$ & $\mathrm{N}$ & $\mathrm{N}$ & $\mathrm{N}$ & $\mathrm{N}$ & $\mathrm{P}$ & 0 \\
\hline & $9 a$ & $\mathrm{~N}$ & $\mathrm{~N}$ & $\mathrm{Y}$ & $\mathrm{N}$ & $\mathrm{N}$ & $\mathrm{P}$ & $\mathrm{Y}$ & $\mathrm{P}$ & $\mathrm{N}$ & $\mathrm{Y}$ & $\mathrm{P}$ & $\mathrm{Y}$ & $\mathrm{P}$ & $\mathrm{Y}$ & $\mathrm{P}$ & $\mathrm{P}$ & $\mathrm{Y}$ & 6 \\
\hline total & & 2 & 3 & 5 & 3 & 1 & 0 & 5 & 0 & 2 & 3 & 2 & 4 & 3 & 6 & 5 & 3 & 3 & 50 \\
\hline \multirow[t]{5}{*}{ Evidence } & $10 \mathrm{a}$ & $\mathrm{N}$ & $\mathrm{N}$ & $\mathrm{Y}$ & $\mathrm{N}$ & $\mathrm{Y}$ & $\mathrm{Y}$ & $\mathrm{P}$ & $\mathrm{Y}$ & $\mathrm{N}$ & $\mathrm{Y}$ & $\mathrm{N}$ & $\mathrm{P}$ & $\mathrm{N}$ & $\mathrm{N}$ & $\mathrm{Y}$ & $\mathrm{Y}$ & $\mathrm{N}$ & 7 \\
\hline & $10 \mathrm{~b}$ & $\mathrm{~N}$ & $\mathrm{~N}$ & $\mathrm{~N}$ & $\mathrm{~N}$ & $\bar{Y}$ & $\mathrm{~N}$ & $\mathrm{~N}$ & $\mathrm{~N}$ & $\mathrm{~N}$ & $\mathrm{~N}$ & $\mathrm{Y}$ & $\mathrm{N}$ & \begin{tabular}{|l}
$P$ \\
\end{tabular} & $P$ & $\mathrm{P}$ & $\mathrm{N}$ & $\mathrm{N}$ & 2 \\
\hline & $11 \mathrm{a}$ & $\mathrm{Y}$ & $\mathrm{Y}$ & $\mathrm{Y}$ & $\mathrm{Y}$ & $\mathrm{Y}$ & $\mathrm{Y}$ & $\mathrm{Y}$ & $\mathrm{Y}$ & $\mathrm{Y}$ & $\mathrm{Y}$ & $\mathrm{Y}$ & $\mathrm{Y}$ & $\mathrm{Y}$ & $\mathrm{Y}$ & $\mathrm{Y}$ & $\mathrm{N}$ & $\mathrm{Y}$ & 16 \\
\hline & $11 \mathrm{~b}$ & $\mathrm{P}$ & $\mathrm{N}$ & $\mathrm{N}$ & $\mathrm{N}$ & $\mathrm{N}$ & $\mathrm{Y}$ & $P$ & $\mathrm{~N}$ & $\mathrm{~N}$ & $\mathrm{~N}$ & $\mathrm{~N}$ & $\mathrm{~N}$ & $\mathrm{P}$ & $\mathrm{Y}$ & $P$ & $\mathrm{P}$ & $\mathrm{N}$ & 2 \\
\hline & 12 & $\mathrm{Y}$ & $\mathrm{Y}$ & $\mathrm{Y}$ & $\mathrm{Y}$ & $\mathrm{Y}$ & $\mathrm{Y}$ & $\mathrm{Y}$ & $\mathrm{Y}$ & $\mathrm{N}$ & $\mathrm{Y}$ & $\mathrm{Y}$ & $\mathrm{Y}$ & $\mathrm{Y}$ & $\mathrm{Y}$ & $\mathrm{Y}$ & $\mathrm{Y}$ & $\mathrm{Y}$ & 16 \\
\hline total & & 2 & 2 & 3 & 2 & 4 & 4 & 2 & 3 & 1 & 3 & 3 & 2 & 2 & 3 & 3 & 2 & 2 & 43 \\
\hline \multirow[t]{7}{*}{ Recommendations } & $13 a$ & $\mathrm{P}$ & $\mathrm{Y}$ & $\bar{Y}$ & $\mathrm{P}$ & $\mathrm{Y}$ & $\mathrm{Y}$ & $\mathrm{Y}$ & $\mathrm{Y}$ & $\mathrm{Y}$ & $\mathrm{Y}$ & $\mathrm{Y}$ & $\mathrm{Y}$ & $\mathrm{Y}$ & $\bar{Y}$ & $\mathrm{Y}$ & $\mathrm{Y}$ & $\mathrm{Y}$ & 15 \\
\hline & $13 \mathrm{~b}$ & $\mathrm{~N}$ & $\mathrm{Y}$ & $\mathrm{N}$ & $\mathrm{N}$ & $\mathrm{N}$ & $\mathrm{N}$ & $\mathrm{N}$ & $\mathrm{N}$ & $\mathrm{N}$ & $\mathrm{N}$ & $\mathrm{N}$ & $\mathrm{Y}$ & $\mathrm{N}$ & $\mathrm{Y}$ & $\mathrm{Y}$ & NA & NA & 4 \\
\hline & $13 \mathrm{c}$ & $\mathrm{Y}$ & $\mathrm{Y}$ & $\mathrm{Y}$ & $\mathrm{Y}$ & $\mathrm{Y}$ & $\mathrm{Y}$ & $\mathrm{Y}$ & $\mathrm{Y}$ & $\mathrm{N}$ & \begin{tabular}{|l|}
$\mathrm{Y}$ \\
\end{tabular} & $\mathrm{Y}$ & $\mathrm{Y}$ & $\mathrm{Y}$ & $\mathrm{Y}$ & $\mathrm{Y}$ & $\mathrm{Y}$ & \begin{tabular}{|l|}
$\mathrm{Y}$ \\
\end{tabular} & 16 \\
\hline & $14 a$ & $\mathrm{~N}$ & $\mathrm{Y}$ & $\mathrm{N}$ & $\mathrm{N}$ & $\mathrm{N}$ & $\mathrm{N}$ & $\mathrm{N}$ & $\mathrm{N}$ & $\mathrm{N}$ & $\mathrm{Y}$ & $\mathrm{N}$ & $\mathrm{N}$ & $\mathrm{N}$ & $\mathrm{N}$ & $\mathrm{N}$ & $\mathrm{N}$ & $\mathrm{P}$ & 2 \\
\hline & $14 \mathrm{~b}$ & $\mathrm{~N}$ & $\mathrm{~N}$ & $\mathrm{~N}$ & $\mathrm{~N}$ & $\mathrm{Y}$ & $\mathrm{N}$ & $\mathrm{N}$ & $\mathrm{N}$ & $\mathrm{N}$ & $\mathrm{N}$ & $\mathrm{N}$ & $\mathrm{N}$ & NA & $\mathrm{N}$ & $\mathrm{Y}$ & $\mathrm{N}$ & $\mathrm{P}$ & 2 \\
\hline & $14 \mathrm{c}$ & $\mathrm{N}$ & $\mathrm{N}$ & $\mathrm{N}$ & $\mathrm{N}$ & $\mathrm{Y}$ & $\mathrm{N}$ & $\mathrm{N}$ & $\mathrm{N}$ & $\mathrm{N}$ & $\mathrm{N}$ & $\mathrm{N}$ & $\mathrm{N}$ & $\mathrm{N}$ & $\mathrm{N}$ & $\mathrm{P}$ & $\mathrm{N}$ & $\mathrm{N}$ & 1 \\
\hline & 15 & $\mathrm{~N}$ & $\mathrm{Y}$ & $\mathrm{Y}$ & $\mathrm{N}$ & $\mathrm{N}$ & $\mathrm{Y}$ & $\mathrm{Y}$ & $\mathrm{Y}$ & $\mathrm{Y}$ & $\mathrm{Y}$ & $\mathrm{Y}$ & $\mathrm{Y}$ & $P$ & $\mathrm{~N}$ & $\mathrm{Y}$ & $\mathrm{Y}$ & $\mathrm{Y}$ & 12 \\
\hline total & & 1 & 5 & 3 & 1 & 4 & 3 & 3 & 3 & 2 & 4 & 3 & 4 & 2 & 3 & 5 & 3 & 3 & 52 \\
\hline $\begin{array}{l}\text { review and quality } \\
\text { assurance }\end{array}$ & 16 & $\mathrm{Y}$ & $\mathrm{Y}$ & $\mathrm{N}$ & $\mathrm{N}$ & $\mathrm{N}$ & $\mathrm{N}$ & $\mathrm{N}$ & $\mathrm{N}$ & $\mathrm{N}$ & $\mathrm{N}$ & $\mathrm{P}$ & $\mathrm{P}$ & $\mathrm{N}$ & $\mathrm{Y}$ & $\mathrm{N}$ & $\mathrm{N}$ & $\mathrm{P}$ & 3 \\
\hline \multirow{4}{*}{$\begin{array}{lr}\text { Funding } & \text { and } \\
\text { declaration } & \text { and } \\
\text { management } & \text { of } \\
\text { interests } & \end{array}$} & $18 \mathrm{a}$ & $\mathrm{Y}$ & $\mathrm{N}$ & $\mathrm{Y}$ & $\mathrm{Y}$ & $\mathrm{N}$ & \begin{tabular}{|l|}
$\mathrm{Y}$ \\
\end{tabular} & $\mathrm{Y}$ & $\mathrm{N}$ & $\mathrm{Y}$ & $\mathrm{N}$ & $\mathrm{Y}$ & $\mathrm{N}$ & $\mathrm{N}$ & $\mathrm{Y}$ & $\mathrm{N}$ & $\mathrm{P}$ & $\mathrm{Y}$ & 9 \\
\hline & $18 \mathrm{~b}$ & $\mathrm{~N}$ & NA & $\mathrm{N}$ & $\mathrm{N}$ & NA & $\mathrm{N}$ & $\mathrm{Y}$ & NA & $\mathrm{N}$ & NA & $\mathrm{N}$ & NA & NA & $\mathrm{N}$ & NA & $\mathrm{N}$ & $\mathrm{N}$ & 1 \\
\hline & $19 a$ & $\mathrm{~N}$ & $\mathrm{~N}$ & $\mathrm{Y}$ & $\mathrm{N}$ & $\mathrm{N}$ & $\mathrm{Y}$ & $\mathrm{Y}$ & $\mathrm{N}$ & $\mathrm{Y}$ & $\mathrm{N}$ & $\mathrm{Y}$ & $\mathrm{Y}$ & $\mathrm{Y}$ & $\mathrm{Y}$ & $\mathrm{Y}$ & $\mathrm{Y}$ & $\mathrm{Y}$ & 11 \\
\hline & $19 b$ & NA & NA & $\mathrm{N}$ & NA & NA & $\mathrm{N}$ & $\mathrm{N}$ & NA & $\mathrm{N}$ & $\mathrm{N}$ & $\mathrm{N}$ & $P$ & NA & $\mathrm{Y}$ & NA & $\mathrm{N}$ & \begin{tabular}{|l|}
$\mathrm{Y}$ \\
\end{tabular} & 2 \\
\hline total & & 1 & 0 & 2 & 1 & 0 & 2 & 3 & 0 & 2 & 0 & 2 & 1 & 1 & 3 & 1 & 1 & 3 & 23 \\
\hline \multirow[t]{3}{*}{ other information } & 20 & $\mathrm{Y}$ & $\mathrm{Y}$ & $\mathrm{Y}$ & $\mathrm{Y}$ & $\mathrm{N}$ & $\mathrm{Y}$ & $\mathrm{N}$ & $\mathrm{N}$ & $\mathrm{Y}$ & $\mathrm{N}$ & $\mathrm{Y}$ & $\mathrm{Y}$ & $\mathrm{N}$ & $\mathrm{Y}$ & $\mathrm{Y}$ & $\mathrm{N}$ & $\mathrm{Y}$ & 11 \\
\hline & 21 & $\mathrm{~N}$ & $\mathrm{~N}$ & $\mathrm{Y}$ & $\mathrm{N}$ & $\mathrm{N}$ & $\mathrm{N}$ & $\mathrm{N}$ & $\mathrm{N}$ & $\mathrm{N}$ & $\mathrm{N}$ & $\mathrm{N}$ & $\mathrm{Y}$ & $\mathrm{N}$ & $\mathrm{N}$ & $\mathrm{Y}$ & $\mathrm{N}$ & $\mathrm{N}$ & 3 \\
\hline & 22 & $\mathrm{~N}$ & $\mathrm{~N}$ & $\mathrm{Y}$ & $\mathrm{N}$ & $\mathrm{N}$ & $\mathrm{Y}$ & $\mathrm{N}$ & $\mathrm{N}$ & $\mathrm{N}$ & $\mathrm{P}$ & $\mathrm{N}$ & $\mathrm{N}$ & $\mathrm{N}$ & $\mathrm{N}$ & $\mathrm{N}$ & $\mathrm{N}$ & $\mathrm{N}$ & 2 \\
\hline \multirow[t]{2}{*}{ Total } & & 1 & 1 & 3 & 1 & 0 & 2 & 0 & 0 & 1 & 0 & 1 & 2 & 0 & 1 & 2 & 0 & 1 & 16 \\
\hline & & 9 & 16 & 21 & 9 & 13 & 16 & 16 & 11 & 12 & 14 & 15 & 18 & 12 & 22 & 18 & 13 & 18 & 253 \\
\hline
\end{tabular}

Figures 

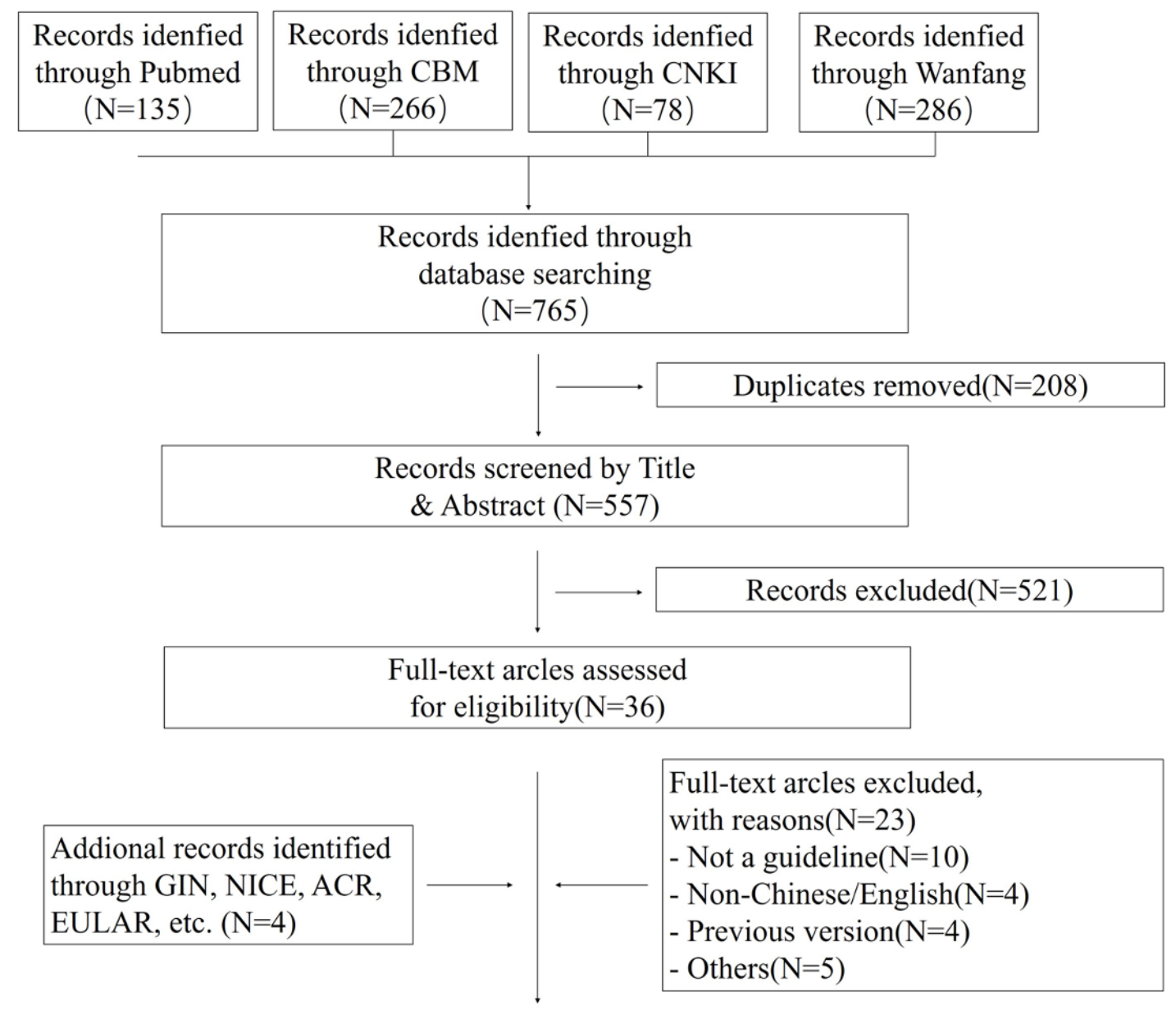

Guidelines included(N=17)

Figure 1

Literature selection flow chart 


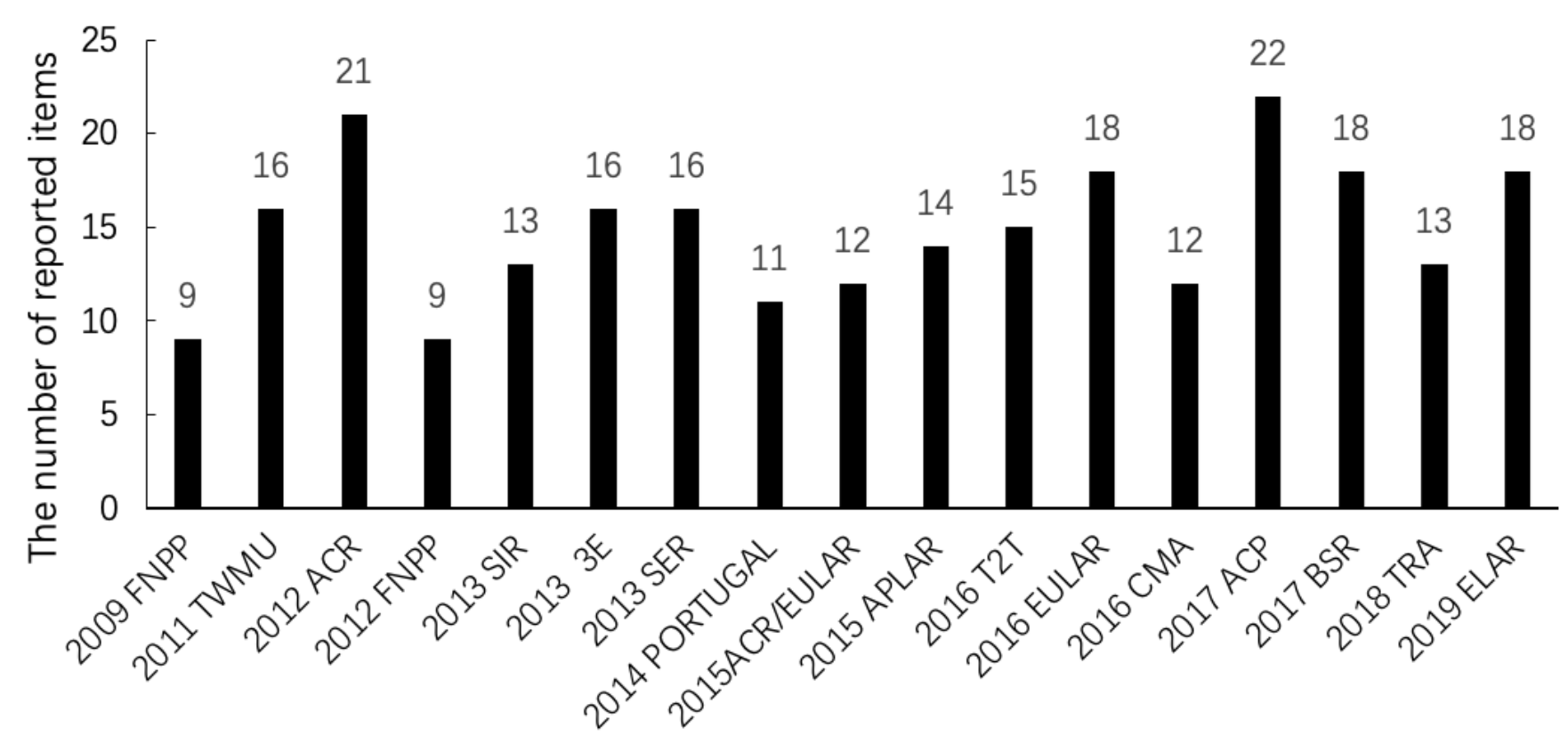

Guidelines

Figure 2

Number of reported items in each guideline

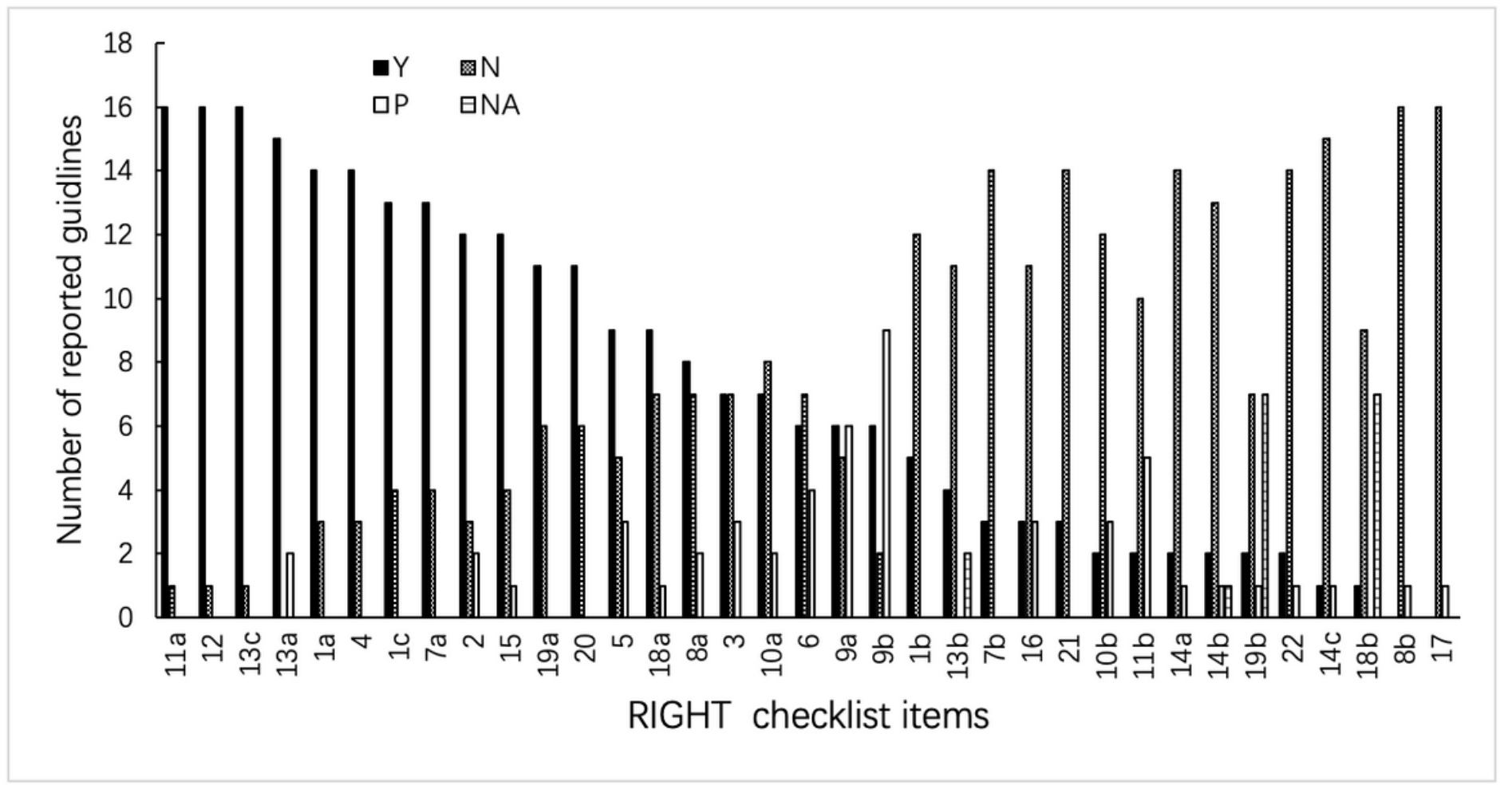

Figure 3

Number of guidelines reporting each item. Notes: Items listed according to the reporting frequency of "Y". 
This is a list of supplementary files associated with this preprint. Click to download.

- Supplementaryfile.docx

Page 12/12 